\title{
Effect of Human-Wildlife Conflict on Food Security among Small-Scale Maize Farmers in Laikipia County, Kenya
}

\author{
Ronald Orare Nyamwamu ${ }^{1}$, Justus Moturi Ombati ${ }^{2}$, John Gowland Mwangi ${ }^{3}$ \\ Department of Agricultural Education \& Extension, Egerton University, P.O Box 536-20115 Egerton, Kenya
}

\begin{abstract}
Agriculture contributes to 30\% of the global Gross Domestic Product and employs more than 2 billion people in the world. In Kenya, the agriculture sector contributes $26 \%$ of total GDP, $18 \%$ formal employment, $65 \%$ of total exports, $70 \%$ informal employment, is a source of employment food and income. However, the agriculture sector is affected by human-wildlife conflict. Although wildife contributes significantly to national economic development, there exists human-wildlife conflict especially in unprotected wildlife habitats. Human-wildlife conflict can significantly contribute to food insecurity. However, information on its effect on food security among small-scale maize farmers in Laikipia County is inadequate and poorly documented. This study sought to establish how human-wildlife conflict affects food security among small-scale maize farmers. Document review and analysis was used in undertaking this study. A document review guide was used to collect data. It was established that human-wildlife conflict causes severe crop damage and livestock injury or even death. Although farmers use various mitigation strategies most of them traditional in nature, significant crop damage is being experienced. It was therefore concluded that human-wildlife conflict could be significantly affecting food security among small-scale maize farmers in Laikipia County. A study should be undertaken to determine the effectiveness of mitigation strategies used by small-scale farmers. Further, a study should be done to establish the influence of agricultural extension mitigation strategies on human-wildlife conflict. The information generated could be used by policy makers and agricultural extension service providers to plan better on how to mitigate the effect of human-wildlife conflict.
\end{abstract}

Keywords: Effect, Food Security; Human-wildlife Conflict, Small-scale Maize Farmer

\section{Introduction}

Agriculture employs more than 2 billion people in the world and contributes $30 \%$ of the global Gross Domestic Product, GDP (Hanson, 2013). In Africa, agriculture sector is vital in achieving food security, employment creation and economic growth (Alliance for a Green Revolution in Africa, AGRA, 2013; Hoffman, 2012). The sector provides income and employment for Africans especially the poor (Ncube et al., 2012). Agriculture also provides good opportunities for economic development in rural areas for most Sub Sahara African countries (International Fund for Agricultural Development, IFAD, 2010). It is also critical for poverty reduction (Schaffnit-Chatterjee, 2014). Economic growth also improves food security by increasing access to food (Meade et al., 2013). The sector being the largest employer in developing countries, its growth significantly increases income generation, reduces poverty and food prices (Asenso-Okyere \& Jemaneh, 2012). A food security situation exists when all people at all times have physical and socio-economic access to enough, safe and nutritious food that meets their dietary needs and preferences for an active and healthy life (FAO, 2009; UNDP, 2012). For food security to be achieved food has to be available, accessible and adequate (Mwaniki, 2012; UNDP, 2012). Raising agricultural production and productivity can sustainably increase farm food supplies and consequently improve food security (Asenso-Okyere \& Jemaneh, 2012; Ncube et al., 2012). In Kenya, since agriculture contributes about $26 \%$ of GDP directly and $25 \%$ indirectly, it is therefore considered the backbone of the country's economy (GoK, 2010). For instance in the year 2010, the sector grew at $6.3 \%$, from negative $2.9 \%$ in 2009 translating to GDP growth from $2.6 \%$ to $5.6 \%$ in the same period (KNBS, 2011). The sector is a source of food, employment and income (Biwott et al., 2013). It also accounts for about $65 \%$ of the total national exports and $18 \%$ of informal employment in rural areas. This shows that agriculture is very critical in the achievement and sustenance of food security.

Wildlife forms the base for the tourism industry (Vernon, 2010; Wanyonyi, 2012). The industry is large and fast growing besides generating 5\% of global GDP in 2011 and $7 \%$ of employment opportunities worldwide (GoK, 2008; UNCTAD, 2013). It is ranked the fourth largest industry in the world (Honey \& Gilpin, 2009). The government of Kenya identifies the tourism industry as one of the growth engines for the national economy (Wanyonyi, 2012). The tourism sector contributes $13 \%$ to Kenya's economy, $12 \%$ of GDP and $19 \%$ of the total wage employment (Vernon, 2010). It contributes significantly to local and national economy (Laikipia Wildlife Forum, LWF, 2012; Ministry of Forestry \& Wildlife, MFW, 2011). This is evidenced by its contribution where in 2005/2006 financial year, tourism generated $25 \%$ GDP and more than $10 \%$ of the total formal sector employment. The sector is therefore identified as one of the key drivers for the achievement of economic development as envisaged in the national development plan called Vision 2030 (Laikipia Wildlife Forum, LWF, 2012). However, the interaction between wildlife and people results in human-wildlife conflict (GoK, 2012; MFW, 2012). Thus, despite wildlife being the base for the tourism industry which is significant in Kenya's economy, it contributes to human-wildlife conflict. 


\section{International Journal of Science and Research (IJSR) \\ ISSN (Online): 2319-7064}

Index Copernicus Value (2013): 6.14 | Impact Factor (2015): 6.391

\section{Statement of the Problem}

Agriculture is important in Kenya's national economic development, income and employment creation and providing raw materials for industries. One of the challenges affecting the agricultural sector is the human-wildlife conflict which results from human encroachment on wildlife habitats. It may also arise from the movement of wildlife out of their unprotected habitats such as Rumuruti Forest or protected areas into adjacent farmland. Despite the humanwildlife conflict being experienced by farmers, the government identifies the tourism industry as one of the key engines of economic development with wildlife being the base for the industry. Wildlife freely and easily moves out of their habitat into the surrounding farmland where they damage crops, injure or kill livestock or even people. Available information on the effect of human-wildlife conflict on household food security among small-scale maize farmers was inadequate or poorly documented. This study sought to avail the information to policy makers and agricultural extension providers to enable them plan better on how to reduce food insecurity arising from humanwildlife conflict.

\section{Objectives of the Study}

This study was guided by the following objectives:

i) To establish the severity of crop damage arising from human-wildlife conflict among small-scale maize farmers in Laikipia County.

ii) To determine the human-wildlife mitigation strategies used by small-scale maize farmers in Laikipia County.

\section{Research Methodology}

This study was conducted through document review and analysis. Document review was achieved using a document review guide which was developed by the researcher and validated by agricultural education and extension experts of Egerton University. The review guide sought to collect information on the severity of crop damage and the mitigation strategies used by small-scale farmers in Laikipia County.

\section{Severity of Human-wildlife Conflict}

Human-wildlife conflict occurs when wildlife requirements encroach on human requirements (FAO, 2009). It is a problem experienced globally in areas where people and wildlife interact and share limited resources (Musimbi, 2013). The conflict is not restricted to any geographical area or climatic condition but it is common in areas where wildlife and people coexist and compete for scarce resources (Le Bel et al., 2011). It is also experienced among people residing adjacent wildlife habitats (Hemson et al., 2009). Human-wildlife conflict involves different birds, mammals, fish, insects and reptiles (Gandiwa, et al., 2013). Wildlife therefore moves out of their habitat and damages crops, injures or kills livestock or even people, transmits diseases and also damages property (FAO, 2009; Musimbi, 2013; Musyoki et al., 2012; Waithaka, 2012). Therefore, conflicts occur between wildlife and the farmers neighboring wildlife habitats (Hill \& Wallace, 2012; Riley \& Priston, 2010;
Strum, 2010). Furthermore, animal-man interaction conflicts have been in existence for as long as humans have existed, and shared landscape and resources in various parts of the world. In America, Bears attack dustbins in towns of Northern USA, Deers collided with automobiles injuring 29,000 animals in Northern Alberta, Canada between 1992 and 1996 wolves killed 2, 806 livestock (cattle and sheep); in Idaho, Montana and Wyomig (USA), between 1987 and 2001, wolves killed 728 livestock (Musimbi, 2013). In Ghana, human-wildlife conflict is common around wildlife conservation and water areas (Stuttgart, 2011). In rural Kenya, the conflict is a significant problem especially in areas where wildlife habitats border farmland (Graham et al., 2009a). The conflict is also prevalent in areas where people live adjacent forest resources (Waithaka, 2012; Wallace \& Hill, 2007). The landscape in Laikipia County holds the second largest wildlife population in Kenya although it is not protected or gazette as a wildlife habitat (Litoroh et al., 2010; Maximillian et al., 2011). Wildlife therefore easily moves out of their habitat into the neighboring landscape which comprises communally-owned pastoral areas and small-scale farms (Graham \& Ochieng, 2008). Further, the use of large areas of natural habitat occupied by wildlife for agricultural activities initiate human-wildlife conflict in form of crop damage (LWF, 2012). This shows that humanwildlife conflict can be severe especially in areas where wildlife habitats border farmland, allowing wildlife to freely move into farmland thus attacking livestock and damaging crops.

Although on a national scale a loss of 2 ha of maize in a single day to wildlife may seem insignificant, to the household concerned it may mean a loss of a year's food supply (Graham et al., 2010). The loss may also mean the difference between self-sufficiency and starvation. Crop damage ultimately affects a household's capacity to feed its members, reduces income, and affects their health, nutrition, education and general community development (FAO, 2009). After crop damage, finances are also diverted from meeting other household needs to buy food. Human-wildlife conflict reduces agricultural productivity and economic opportunities (Ministry of Natural Resources of Ontario, MNRO, 2008). Out of the 1 billion people who are undernourished in the world, about $30 \%$ (239million) live in Africa (Mwangi et al., 2013; UNESC, 2012). This results from low agricultural production and poverty (Mwangi et al., 2013; Ncube et al., 2012). In East Africa, it results from low harvests, civil insecurity and human-wildlife conflicts (GoK, 2012; Kathuri et al., 2011; Stufftung, 2011). Consequently, whereas Africa imported 43 million tonnes of food in 2011, Kenya has experienced food deficits over successive years (Stufftung, 2012). Food security is low in the pastoral areas of African countries (Ncube et al., 2013). The agro-pastoralist clusters in Kenya cover the areas of Kajiado, West Pokot, Baringo, Kieni East, Kieni West and Laikipia Sub Counties (GoK, 2012). Maize crop is a major staple food in Kenya and therefore its deficits and unavailability is considered synonymous with low food security (Stufftung, 2011). In Laikipia County, staple foods include maize, potatoes and beans. Maize deficits in Kenya was up to $35 \%$ below the annual average production in 2011, necessitating imports (GoK, 2012). A total of 3,750, 700 and 2, 157, 800 people needed food aid in the pastoral 


\section{International Journal of Science and Research (IJSR) \\ ISSN (Online): 2319-7064 \\ Index Copernicus Value (2013): 6.14 | Impact Factor (2015): 6.391}

and marginal areas of Kenya in 2011 and 2012 respectively (GoK, 2012). During the same period, in Laikipia County, about 61,900 and 56, 600 people needed relief food in 2011 and 2012 respectively. This might have been caused by a decline in maize production (GoK, 2013). The maize deficits experienced in Laikipia County could be resulting from the human-wildlife conflict experienced among the small-scale farmers. This shows that human-wildlife conflict has a potential to affect the food available to a household through crop damage

\section{Human-wildlife Conflict Mitigation Strategies}

Farmers use different strategies to mitigate human-wildlife conflict such as guarding (animal \& human), barriers (fence, trench, walls or erecting a buffer zone) or repellents (chemical, auditory) (Treeves, 2007). Some farmers grow crops that are unpalatable to wildlife and also grow heavily attacked crops beyond a buffer of unappealing crops (Hocking \& Humle, 2009). Others chase or scare away wildlife while others use African honey bees as barriers against wildlife (Karidozo \& Osborn, 2007; King et al., 2011). In Uganda, small-scale farmers use barriers like fences, humans guard against wildlife and also use repellents (Wallace \& Hill, 2007). Farmers in Mozambique make loud noise and light fires to scare away wildlife, and also use chilli barriers (Anderson \& Parieda, 2005). The Kenya Wildlife Service promotes the growing of crops that are unappealing to wildlife such as chilli or establishment of barriers such as ditches (Hocking \& Humle, 2009; Musimbi, 2013). Agriculture extension also promotes growing of unpalatable crops such as chilli, digging of trenches, agroforestry practices, use of African honey bees and life fences (Karidozo \& Osborn, 2007; King et al., 2011; Mc Guinnes \& Taylor, 2014; MoA, 2009). In Laikipia County, extension also promotes forest conservation, fodder production and fruit and woodlot production (GoK, 2013). Farmers in the Tsavo Conservation Area (TCA) of Kenya make loud noise, erect scare crows, burn hot pepper and light fire to scare away wildlife (Makindi et al., 2014). They also burn animal manure to produce offensive smell, guard using dogs besides chasing away the wildlife. In Laikipia County, farmers use traditional wildlife mitigation strategies such as lighting fire, use watch towers, make loud noises and guard their farms against invasion by wildlife (Graham et al., 2009b). The farmers also use farm-based deterrents such as fire-works, powerful lights and chilli-grease fences. This shows that small-scale farmers including those in Laikipia County use various traditional human-wildlife mitigation strategies. Despite the various strategies being promoted and farmers adopting some of the strategies, they still experience significant crop damage.

\section{Research Results, Conclusion and Recommendations}

This study established that human-wildlife conflict is common in areas where wildlife and people share and compete for resources, especially where farmers border wildlife habitats. In some cases wildlife habitats are not protected thus allowing wildlife to easily move into adjacent farmland. Wildlife therefore moves into the neighboring farms frequently and damage crops severely by up to $98 \%$ of total hacterage. Such severe crop damage significantly affects the overall crop yield. Wildlife move into the farmland neighboring their habitat frequently and severely damage crops. Additionally, small-scale farmers use various human-wildlife conflict mitigation strategies, most of them being traditional in nature. It was therefore concluded that small-scale maize farmers in Laikipia County could be suffering from food insecurity resulting from the effect of human-wildlife conflict. It was therefore recommended that a study be undertaken to establish the effectiveness of human-wildlife conflict mitigation strategies used by smallscale farmers in Laikipia County. Further, a study should be done to determine the influence of agricultural extension mitigation strategies on human-wildlife conflict among small-scale farmers in Laikipia County.

\section{References}

[1] Alliance for a Green Revolution in Africa. (2013). Africa Agriculture Status Report: Focus on Staple Crops. Nairobi, Kenya. AGRA.

[2] Anaeto, F. C., Asiabaka, C.C., Nnadi, F. N., Ajaero, J .O., Aja, O. O., Ugwoke, F .O., Ukpongson, M. U. \& Onweagba, A. E. (2012). The Role of Extension Officers and Extension Services. In: The Development of Agriculture in Nigeria. Wudpecker Journal of Agricultural Research Vol.1 (6), 180-185. Available online at http://www.wudpecker researchjournals.org.

[3] Anderson, J. L. \& Parieda, F. (2005). Strategies to Mitigate Human-Wildlife Conflicts-Mozambique Wildlife Management. Working Paper no.8.FAO Rome, Italy.

[4] Anderson, J. R. (2008). Agricultural Advisory Services: Background Paper for the World Development Report, 2008. Retrieved from siteresources.worldbank.org/.../ Anderson _AdvisoryServices.pdf on 21/5/2013.

[5] Asenso-Okyere, K. \& Jemaneh, S. (2012). Increasing Agricultural Productivity \& Enhancing Food Security in Africa. New Challenges \& Opportunities. Synopsis of an International Conference.doi.org/10.2499/9780896297937.

International Food Policy Research Institute (IFPRI). Washington, DC.

[6] Biwott, H., Kenya Institute of Economic Affairs, Kenya International Institute of Legal Affairs \& Muriu, A. R. (2013). Agriculture Sector Functional Analysis: A Policy, Regulatory and Legislative Perspective.

[7] CGIAR. (2013). "Research On Agricultural Extension Systems: What Have We Learnt and Where Do We Go From Here?" Workshop Organized by the CGIAR Research Program on Policies, Institutions and Markets. October 15-16, Washington D.C, USA.

[8] Eniang, E. A., Ijeomah, H. M., Okeyoyin, G. \& Uwatt, A. E. (2011). Assessment of Human-Wildlife Conflicts in Filinga Range of Gashaka Gumti National Park, Nigeria. Publication of Nasarawa State University, Keffi, PAT, 7 (1), 15-35. Retrieved from http://www.patnsukjournal.net/currentissue

[9] Eyebe, A. J., Dkamela, G. P. \& Endomana, D. (2012). Overview of Human-Wildlife Conflict in Cameroon.

\section{Volume 5 Issue 6, June 2016 www.ijsr.net}




\section{International Journal of Science and Research (IJSR) \\ ISSN (Online): 2319-7064}

Index Copernicus Value (2013): 6.14 | Impact Factor (2015): 6.391

Poverty and Conservation Learning Group Discussion Paper No. 05.

[10] Food Agricultural Organization of the United Nations (2009). Human Wildlife Conflict in Africa-Causes, Consequences and Management Strategies. FAO Forestry paper 157 . Rome.

[11] Gandiwa, E., Heitkonig, I. M. A., Lokhorst, A. M., Prins, H. H. T. \& Leeuwis, C. (2013). CAMPFIRE and Human-Wildlife Conflicts in Local Communities Bordering Northern Gonarezhou National Park, Zimbabwe. Ecology and Society, 18 (4), 7. http://dx.doi.org /10.h'5751/Es-05817-180407.

[12] GoK. (2008). Ministry of Tourism: Medium Term Plan (2008 - 2012). Tourism Sector Report. Nairobi, Kenya. Ministry of Tourism. Available at www.tourism.go.ke

[13] GoK. (2010). Agricultural Sector Development Strategy (2010-2020). Nairobi; Kenya: Government Printers.

[14] GoK, FAO \& WFP. (2012). The 2011/12 Short Rains Season Assessment Report. Kenya Food Security Steering Group (KFSSG).

[15] GoK. (2013). Kenya Gazette Supplement No. 181 (Acts No. 47): The Wildlife Conservation and Management Act 2013. Nairobi, Kenya. Government Printer

[16] Graham, M. D. \& Ochieng, T. (2008). Uptake and Performance of Farm-based Measures for Reducing Crop Raiding by Elephants, Loxodonta Africana, Among Farms in Laikipia District, Kenya. Oryx, 42 (1), 76-82. Doi: 10.1017/s00306005308000677.

[17] Graham, M. D., Gichohi, N., Kamau, F., Aike.G., Craig, B., Douglas-Hamilton, I. \& Adams, W. M. (2009a). The Use of Electric Fences to Reduce Human-Elephant Conflict: A Case Study of the OlPejeta Conservancy, Laikipia District, Kenya. Working Paper 1, Laikipia Elephant Project, Nanyuki, Kenya.

[18] Graham M. D., Nyumba, T. O., Kahiro, G., Mutugi, K. and Adams, W. M. (2009b). The Use of Community Drama in the Mitigation of Human-Elephant Conflict, Laikipia, Kenya. Laikipia Elephant Project, Nanyuki, Kenya.

[19] Graham, M. D, Notter, B., Adams, W. M., Lee, P. C. \& Ochieng, T. N. (2010). Patterns of Crop-Raiding by Elephants, Loxodonta Africana, in Laikipia, Kenya, and the Management of Human-Elephant Conflict, Systematics and Biodiversity, 8:4, 435-445. Doi: $1080 / 14772 \quad 000.2010 .533716$. Retrieved from www.dx.doi.org/10.1080/14772000. 2010.533716

[20] Hanson, C. (2013). Food Security, Inclusive Growth, Sustainability, and the Post-2015 Development Agenda. Background Research Paper

[21] Hemson, G., Macclennan, S., Mills, G., Johnson, P. \& Macdonald, D. (2009). Community, Lions, Livestock and Monkey: Spatial and Social Analysis of Attitudes to Wildlife and the Conservation Value of Tourism in a Human-Carnivore Conflict in Botswana; Biological conservation, 142, 2718-2725. Online: http://dx.doi.org/10.1016/j. biocom. 2009.06.024.

[22] Hill, C. M., \& Wallace, G. E. (2012). Crop Protection and Conflict Mitigation: Reducing the Cost of Living alongside Non-Human Primates. Biodiversity and Conservation, 21, 2569-2587.
[23] Hockings, K. \& Humle, T. (2009). Best Practice Guidelines for the Prevention and Mitigation of Conflict between Humans and Great Apes. Gland, Switzerland. IUCN/SSC Primate Specialist Group, Gland, Switzerland.

[24] Hoffman, T. S., \& O’Riain, J. M. (2012). Monkey Management: Using Spatial Ecology to Understand the Extent and Severity of Human-Baboon-Conflict in the Cape Pennisula, South Africa. Ecology and Society, 17 (13). http://dx.doi.org/10.5751/ES-04882-170313.

[25] International Fund for Agricultural Development (IFAD) (2010). Rural Poverty Report 2011: New Realities: New Challenges: New Opportunities for Tomorrow's Generation. International Fund for Agricultural Development, Rome.

[26] Karidozo, M. \& Osborn, F. V. (2007). HumanElephant Conflict Trials in Zimbabwe: Can bees deter Elephants from Raiding Crops? In: Walpole, M. \& Linkie, M. (eds). Proceedings of a Symposium on Mitigating Human-Elephant Conflict: Case Studies from Africa and Asia. Cambridge, UK. Pp.29-36. ISBN: 9781903703267.

[27] Kathuri, N. J., Olubandwa, A. M., \& Wesonga, T. O. E. (2011). Effective Methods for Increased Food Production in Kakamega District. Journal of Agricultural Extension and Rural Development, 3 (5), 95-101.

[28] Kenya National Bureau of Statistics (2011). Kenya Economic Survey Highlights Presented During Kenya Economic Survey 2011 on 17th May 2011 by Wycliffe Ambetsa Oparanya, Nairobi; Kenya.

[29] Kidanemariam, G. E., Mathijs, E., Deckers, J., Gebrehiwot, K., Bauer, H. \& Maertens, M. (2013). The Economic Impact of a New Rural Extension Approach in Northern Ethiopia. Bio-economics Working Paper Series. Working Paper No. 2013/2.

[30] King, L. E., Douglas-Hamilton, I. \& Fritz Vollrath, F. (2011). Bee-Hive Fences are Effective Deterrents for Crop Raiding Elephants. Field Trials in Northern Kenya. African Journal of Ecology 49 (4): 431-439.

[31] Laikipia Wildlife Forum. (2012). A Wildlife Conservation Strategy for Laikipia County (20122030). First Edition. Nanyuki, Kenya. Retrieved from http://www.laikipia.org.

[32] Lauren-Bond, J. (2013). Human (in) Security of the Livestock Crop-wildlife Nexus: The Case of Laikipia County, Kenya. IFRO PhD Thesis. University of Copenhagen, Denmark.

[33] Le Bel, S., Murwira, A., Mukamuri, B., Czudek, Taylor, R. \& La Grange, M. (2011). Human Wildlife Conflicts in Southern Africa: Riding the Whirl Wind in Mozambique and in Zimbabwe, the Importance of Biological Interactions in the Study of Biodiversity. Available from: http://www intechopen.com/books/the-importance-of biologicalinter actions-in-the-study-ofbiodiversity/human-wildlife-conflicts-in-southernafrica-riding-the-whirl-wind-inmozambique-and-inzimbabwe

[34] Litoroh, M., Ihwagi, F. W., Mayienda, R., Bernard, J. \& Douglas-Hamilton, I. (2010). Total Aerial Count of Elephants in Laikipia-Samburu Ecosystem in 


\section{International Journal of Science and Research (IJSR) \\ ISSN (Online): 2319-7064}

Index Copernicus Value (2013): 6.14 | Impact Factor (2015): 6.391

November 2008. Kenya Wildlife Service, Nairobi, Kenya.

[35] Makindi, S. M., Mutinda, M. N., Olekaikai, N. K. W., Olelebo, W. L. \& Aboud, A. A. (2014). Humanwildlife Conflicts: Causes and Mitigation Measures in Tsavo Conservation Area, Kenya. International Journal of Science and Research (IJSR). Online: 23197064). Impact Factor (2012): 3.358. Vol. 3, Issue 6.

[36] Maximilian, D. G., William, M. A. \& Kahiro, N. G. (2011). Mobile Phone Communication in Effective Human Elephant-Conflict Management in Laikipia County. Nanyuki, Kenya. International Oryx; the International Journal of Conservation.doi: 10.1017 /S003060531 1001104.

[37] Mc Guinnes, S. \& Taylor, D. (2014). Farmers' Perceptions and Actions to Decrease Crop Raiding by Forest Dwelling Primates around Rwandan Forest Fragment, Human Dimensions of Wildlife: An International Journal, 19: 2, 179-190. Doi: 10. 1080/1087-

1209.2014.853330.http://dx.doi.org/10.1080/10871209 .2014 .853330

[38] Meade, Birgit, \& Stacey, R. (2013). International Food Security Assessment, 2013-2023, GFA-24, U.S. Department of Agriculture, Economic Research Service.

[39] Ministry of Agriculture. (2009). Strategic Plan 20082012. Nairobi; Kenya: Author

[40] Ministry of Forestry \& Wildlife (2011). Draft Wildlife Policy. Nairobi; Kenya. Government Printers. Retrieved from ww.kws.org/export/sites/kws/info/.../acts.../ Draft_Wildlife_Policy.pdf on 12/8/2013.

[41] Ministry of Forestry \& Wildlife (2012). The National Wildlife Conservation and Management Policy, 2012. Nairobi: Kenya, Ministry of Forestry \& Wildlife.

[42] Ministry of Natural Resources of Ontario. (2008). Strategy for Preventing and Managing Human-Wildlife Conflicts in Ontario. Retrieved from www.mnr.gov.on.ca /stdprod consume/groups/lr/@mnr/.../244546.pdf on 23/7/2013.

[43] Musimbi, M. (2013). Factors Influencing Humanwildlife Conflict in Communities around the Park: A Case of Lake Nakuru National Park, Kenya. Masters' thesis, University of Nairobi, Kenya.

[44] Musyoki, C., Andanje, M. S., Chege, M., Anyona, G., Lukaria, L. \& Kuloba, B. (2012). Challenges and Opportunities for Conserving Some Threatened Species in Kenya: The George Wright Forum, vol.29, No. 1, pp. 81-89.

[45] Mwangi, S. K., Routman, B. \& Westbury, A. (2013). Policy Paper. CAADP at 10: Progress toward Agricultural Prosperity. Africa Growth Initiatives at Brookings.

[46] Mwaniki, A. (2012). Achieving Food Security in Africa: Challenges and Issues. Cornell University, U.S. Plant, Soil and Nutrition Laboratory.

[47] Ncube, M., Elkheshen, K., Leyeka, C. \& Beileh, A. L. (2012). Highlights of the Food Security Situation in Africa. AfDB Quarterly Bulletin Issue 3.

[48] Parker, G. E., Osborn, F. V., Hoare, R. E. \& Niskanen, L. S. (eds). (2007). Human-elephant Conflict Mitigation: A Training Course for Community-Based
Approaches in Africa. Trainer's Manual. Elephant Pepper Development Trust, Livingtone, Zambia and IUCN/SSC AfESG, Nairobi, Kenya. Available at http://www.african-elephant.org/Hec/ pdf/heccombaptmen.Pdf.

[49] Peterman, A., Behrman. J. \& Quisumbling, A. (2011). A Review of Empirical Evidence on Gender Difference in non-land Agricultural Inputs, Technology and Services in Developing Countries. ESA Working Paper No. 11-11. Rome, Italy. Food and Agriculture Organisation of the United Nations

[50] Riley, E. P. \& Priston, N. E. (2010). Macaques in Farms and Folklore: Exploring Human-Non Human Primate Interface in Sulawesi, Indonesia: American Journal of Primatology, 71, 1-7.

[51] Schaffnit-Chatterjee. (2014). Agricultural Value Chains in Sub Saharan Africa. From a Development Challenge to a Business Opportunity. Current Issues: Emerging Markets. Deusche Bank Research. Germany. Retrieved from http://www.dresearch.com

[52] Strum, S. (2010). The Development of Primate Raiding: Implications for Management and Conservation. International Journal of Primatology, 31, 133-156.

[53] Stufftung, H. B. (2011). Perspectives. Political analysis and commentary from Africa: Food Security in Africa. Heinrich Böll Foundation, Southern Africa. Cape Town, South Africa.

[54] Stuttgart, F. K. H. (2011). Effects of Human-Wildlife Conflicts on Food Security around the Bia Conservation Area, Ghana. Diploma Thesis. https://troz.uni-hohenheim.de/.../troz Deckblatt_Abstract_Harich.pdf on 17/ 7/2013.

[55] Swanson, B. E. (2008). Global Review of Good Agricultural Extension and Advisory Service Practices. FAO of the United Nations, Rome, Italy.

[56] Treves, A. (2007). Balancing the Needs of People and Wildlife: When Wildlife Damage Crops and Prey on Livestock. Land Tenure, USAID.

[57] UNCTAD. (2013). Sustainable Tourism: Contribution to Economic Growth and Sustainable Development. Expert Meeting on Tourism's Contribution to Sustainable Development, 14-15 March 2013.UN Conference on Trade and Development, Geneva Switzerland.

[58] UNDP. (2012). Africa Human Development Report 2012: Towards a Food Secure Future. Regional Bureau for Africa (RBA) 1 UN Plaza, New York, NY 10017, USA. Available at https://unp.un.org; www.undp.org/africa and www.afhdr.org

[59] United Nations Economic and Social Council, (UNESC) (2012). Economic Commission for Africa. Eighth Session of the Committee on Food Security and Sustainable Development and Regional Implementation Meeting for the Twentieth Session of the Commission on Sustainable Development. Addis Ababa, Ethiopia.

[60] Vernon, R. B. (2010): The Contribution of Hunting Tourism: How Significant is this to National Economies? In: Contribution of Wildlife to National Economies. Joint Publication of FAO and CIC. Budapest. 72 pp. Hungary. Available online at www.fao.org or www.cic-wildlife.org

\section{Volume 5 Issue 6, June 2016 www.ijsr.net}




\section{International Journal of Science and Research (IJSR) \\ ISSN (Online): 2319-7064}

Index Copernicus Value (2013): 6.14 | Impact Factor (2015): 6.391

[61] Waithaka, J. (2012). The Kenya Wildlife Service in the $21^{\text {st }}$ Century: Protecting Globally Significant Areas and Resources; Historical Factors that Shaped Wildlife Conservation in Kenya. The George Wright Forum, 9 (1), 21-29.

[62] Wallace, G. \& Hill, C. (2007). Development of Techniques to Reduce Farmer-Wildlife Conflict Associated with Crop-Raiding in Masindi District, Uganda. The Rufford Maurice Laing Foundation.

[63] Wanyonyi, E. W. (2012). Mobilizing Resources for Wildlife Conservation in Kenya beyond the $21^{\text {st }}$ Century: The George Wright Forum, Vol.29, No. 1. pp. 118-125. Retrieved from www.georgewright.org/291wanyonyi.pdf on 11/7/2013.

[64] Zivkovic, D., Jelic, S. \& Rajic, Z. (2009). Agricultural Extension Service in the Function of Rural Development. Paper Prepared for Presentation at the $113^{\text {th }}$ EAAE Seminar. "The Role of Knowledge, Innovation and Human Capital in Multifunctional Agriculture and Territorial Rural Development", Belgrade, Republic of Serbia. December 9-11, 2009.

Volume 5 Issue 6, June 2016 www.ijsr.net 